\title{
Human-nature connectedness and other relational values are negatively affected by landscape simplification: insights from Lower Saxony, Germany
}

\author{
Maraja Riechers $^{1} \mathbb{D} \cdot$ Berta Martín-López $^{1} \cdot$ Joern Fischer $^{1}$
}

Received: 25 March 2020 / Accepted: 4 February 2021 / Published online: 9 April 2021

(c) The Author(s) 2021

\begin{abstract}
Landscape simplification is a worldwide phenomenon that impacts biodiversity in agricultural landscapes. Humans benefit greatly from nature's contributions to people in both material and immaterial ways, yet landscape simplification can undermine these contributions. Landscape simplification can have negative consequences, for example, for human-nature connectedness and other relational values. Major and rapid land-use change, together with a declining appreciation of nature by individuals and societies, in turn, could cause a downward spiral of disconnections. Our empirical research combined a comprehensive assessment of five dimensions of human-nature connectedness with the lens of relational values to assess how these are influenced by landscape simplification. Focusing on two rural landscapes with differing agricultural development in Lower Saxony (Germany), we conducted 34 problem-centred interviews. We found that landscape simplification, especially if rapid, negatively influenced human-nature connectedness and particular relational values such as social relations, social cohesion or cultural identity. We postulate that human-nature connectedness might have a balancing influence on preserving relational values, buffering negative impacts of landscape simplification. Losing connections to nature could potentially foster conflicts among actors with different values. We conclude that combining the notions of human-nature connectedness and relational values can generate valuable insights and may help to uncover new ways to foster sustainability.
\end{abstract}

Keywords Agricultural systems $\cdot$ Cultural landscapes $\cdot$ Leverage points $\cdot$ Social-ecological systems $\cdot$ Sustainability

\section{Introduction}

Landscape simplification is the most important driver of change negatively impacting biodiversity and nature's contributions to people (IPBES 2019; Díaz et al. 2019). Landscape simplification often involves a loss of multifunctional, cultural agroecosystems and the expansion of monofunctional, intensive croplands (Foley et al. 2005). This trend poses a major threat to terrestrial ecosystems because it causes declines in wild and farmland biodiversity (Green et al. 2005; Tscharntke et al. 2005), the diversity of crop

Handled by Shizuka Hashimoto, University of Tokyo, Japan.

Maraja Riechers

Riechers@leuphana.de

1 Faculty of Sustainability, Leuphana University Lueneburg, Universitätsallee 1, 21335 Lueneburg, Germany varieties (FAO 2011) and threatens the stability of farmer incomes (Di Falco and Perrings 2003; Abson et al. 2013). Underpinning these proximate drivers of landscape simplification, in turn, are value systems subscribing to economic growth, instrumentalism, utilitarianism and consumerism (Meadows et al. 1972; Fischer et al. 2014). Shaped by such value systems and at the same time reinforcing them, national and supra-national agricultural regulations further help to entrench structural changes in agricultural landscapes (e.g. Mikulcak et al. 2013). A potentially important but poorly understood consequence of landscape simplification is its effects on nature's contributions to people (NCP) (Díaz et al. 2019)—defined as "all the contributions, both positive and negative, of living nature to people's quality of life" (Díaz et al. 2018). The effect of landscape simplification is especially remarkable on non-material NCP that result from the relations between humans and nature (i.e. human-nature connectedness; see Ives et al. 2017) and on the relationships 
among humans that are fostered by nature (e.g. social relations, cultural identity; see Riechers et al. 2020b).

Research on human-nature connectedness is in need of a comprehensive understanding of what connectedness means and how to foster it. Connections between humans and nature are said to have positive influences on health (Maller et al. 2006; Shanahan et al. 2016), on the cognitive development of children (cf. Taniguchi et al. 2005) and overall happiness and well-being (Capaldi et al. 2014). Some scholars claim that we need a stronger connection with nature (Zylstra et al. 2014) because humanity's growing disconnection from nature exacerbates the global environmental crisis (Folke et al. 2011). As the literature is fragmented between disciplines, concepts and operationalization of human-nature connectedness (and related concepts/terms such as "connectedness to nature", Mayer and Frantz 2004; or "nature relatedness", Nisbet et al. 2009) are differently understood and applied with few overlaps across different research fields (Ives et al. 2017). Recent research differentiated five dimensions of human-nature connectedness: (1) a material dimension, such as food, fuel, or artisan goods; (2) an experiential dimension covering nature visits or specific activities in nature, (3) an emotional dimension including spirituality, aesthetics and sense of place, (4) a cognitive dimension which deals with knowledge and awareness, and (5) a philosophical dimension of connectedness that concerns normativity and values of a good life (Ives et al. 2017, 2018). Studying human-nature connectedness through such a comprehensive framework can provide insights about the diverse and multiple ways in which people connect with nature. Yet, empirical applications of multiple dimensions of human-nature connectedness are rare to date, despite their potential to provide insights on how to foster sustainability through (re)connecting humans with nature (Folke et al. 2011; Zylstra et al. 2014; Soga and Gaston 2016).

In addition to ecological changes, and changes to human-nature connectedness, landscape simplification can also impact the social relationships within landscapes-most notably because monofunctional landscapes often provide fewer NCP from which a small number of privileged actors benefit, thereby creating inequity and social conflicts (Fischer et al. 2017; Grass et al. 2019). To study environmentally mediated social relationships between individuals and groups of people, the lens of relational values has been proposed (Pascual et al. 2017). Relational values describe the "preferences, principles, and virtues associated with relationships, both interpersonal and as articulated by policies and social norms" (Chan et al. 2016). These include people's experiences, habits and actions with respect to nature and with respect to relationships of people in nature that are associated with a meaningful, ethically responsible and satisfying life (Himes and Muraca 2018). Since relational values can derive from physical, cognitive and emotional experiences of people in nature, this lens also embraces human-nature connectedness. In addition, relational values also include moral considerations regarding what is considered a good life (eudaimonic values) (Chan et al. 2018). Relational values thus acknowledge a plurality of sources of people's quality of life, heuristically divided into (1) the human collective, such as cultural identity, social cohesion, social responsibility and moral responsibility to nonhumans, and (2) primarily individual values such as individual identity, values for a good life (stewardship eudaimonic) and the normative goal of protecting nature (stewardship principle) (Chan et al. 2016; Pascual et al. 2017). Despite the relevance of relational values for guiding policy-making and management towards a more sustainable world (Chan et al. 2018), empirical research on relational values remains scarce (but see exceptions such as Arias-Arévalo et al. 2017; Klain et al. 2017; Chapman et al. 2019; Topp et al. 2020).

Empirical research on the interplay between human-nature connectedness and relational values is lacking, yet a better understanding of such interplay could generate valuable insights for more sustainable landscape management (Stenseke 2018; Chapman et al 2019). In this explorative, empirical study, we combine a comprehensive assessment of human-nature connectedness with a relational values lens to understand how landscape simplification affects the interlinkages between humans and nature. We studied two agricultural landscapes in Lower Saxony, Germany, which experienced different trajectories of landscape simplification. We sought to (i) understand differences in human-nature connectedness, (ii) examine the interplay between human-nature connectedness and relational values, and (iii) compare how the two contrasting trajectories of landscape simplification affected the interplay between human-nature connectedness and relational values.

\section{Methods}

\section{Study areas}

In Lower Saxony, Germany, agricultural landscapes have been increasingly intensified. Especially the area used for maize cultivation nearly doubled from about $10 \%$ of the total agriculturally used land in the mid 1990 s to about $20 \%$ in 2015 (area used for silage and grain maize; Landesamt für Statistik Niedersachsen 2018a,b), mainly due to a change in policies fostering biogas plants. We considered two study areas. The first was the commune of Bispingen (district Heidekreis), which is located in the south of the Lueneburg Heath (Lüneburger Heide) (Fig. 1b). The Lueneburg Heath is a natural park established in 1907 through the Federal Nature Conservation Act and is subject to specific environmental protection. With 6411 inhabitants in 2016 and 128 
Fig. 1 Study areas situated in Lower Saxony (a), exemplary photos and short descriptions of the study area b Dötlingen (district Oldenburg) and c Bispingen (district Heidekreis)

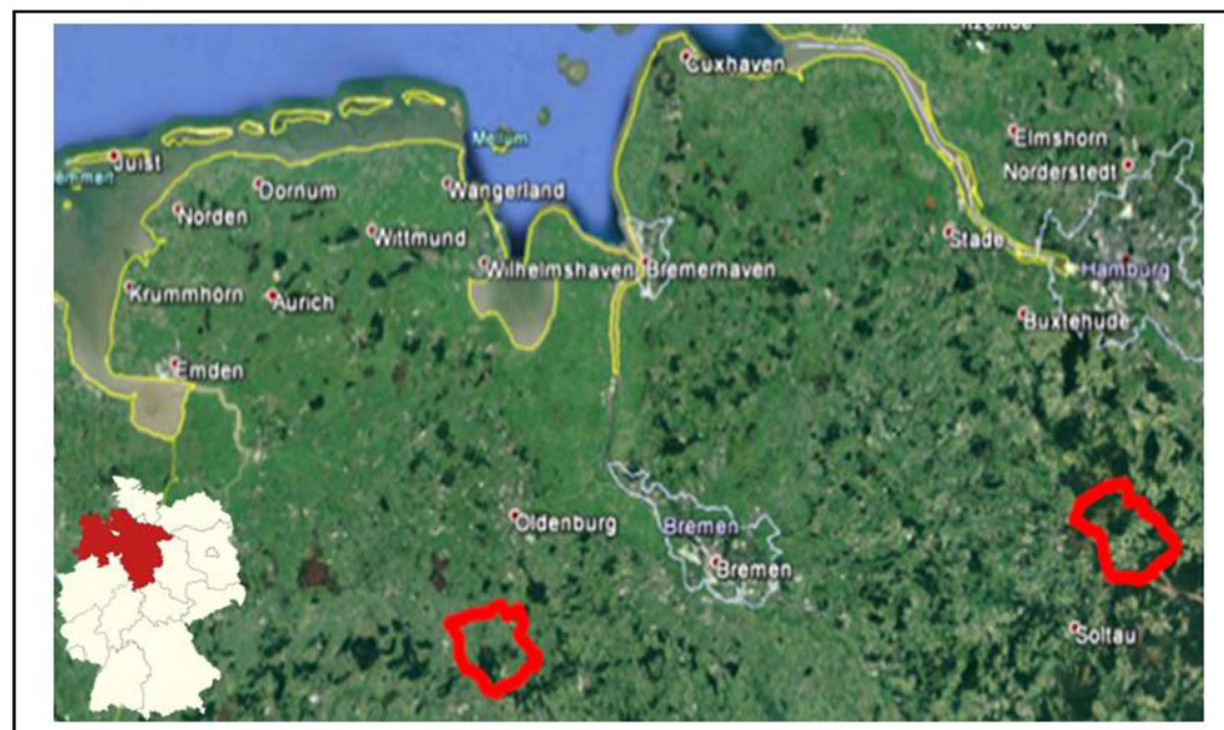

(a) Lower Saxony, Germany: Dötlingen (left), Bispingen (right)

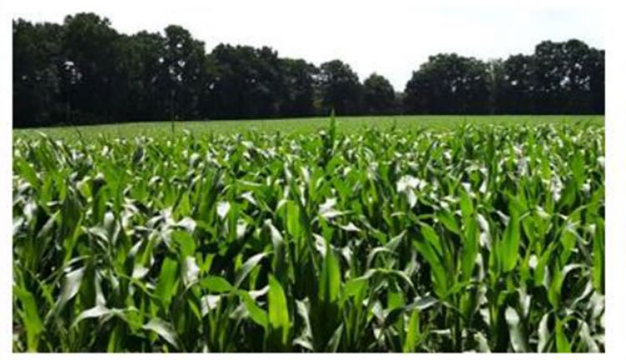

(b) Dötlingen, Landkreis Oldenburg Intensive agriculture; rapid and major land use change

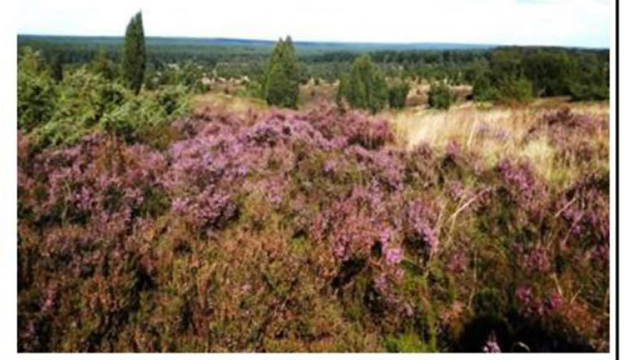

(c) Bispingen, Heidekreis Agriculture and infrastructure development limited; gradual land use change $\mathrm{km}^{2}$ of surface, Bispingen had a population density of 50 inhabitants $/ \mathrm{km}^{2}$ (LSN 2019a). As some areas of Bispingen are inside the natural park, various restrictions on land-use change, development and infrastructure exist. Apart from nature tourism, a newly gazetted commercial area includes tourist destinations. In 2017, 3865 ha (30\% of the total land area) of Bispingen was used for agriculture (LSN 2019b).

The second study area, the commune of Dötlingen, lies in the district of Oldenburg, which is located to the South-East of the city of Oldenburg in the mid-western part of Lower Saxony (Fig. 1c), Germany. In the district of Oldenburg the number of biogas plants increased from the first one built in 1998 to 88 in 2017 (existing, in construction, and in process on 4 July 2017, Landkreis Oldenburg (2018)), leading to an increase in maize production in the area. The commune of Dötlingen covers an area of $102 \mathrm{~km}$ and in 2016 had 6,217 inhabitants (population density of 61 inhabitants $/ \mathrm{km}^{2}$ ) (LSN 2019a). While it is part of the natural park Wildeshauser
Geest, it is not subject to strong environmental protection regulations. Sixty-five percent of the total surface in Dötlingen (i.e. $6628 \mathrm{ha}$ ) is used agriculturally (LSN 2019b), predominantly as cropland.

\section{Data collection}

Data was collected using problem-centred interviews with a semi-structured interview guideline that was adjusted in parts to the interviewees' profession (Flick 2006). The guideline included sections on interviewees' material, experiential, cognitive, emotional and philosophical connectedness, which were assessed, among others, through questions on the use of local natural products, habits and frequency of nature visits, knowledge of nature and the landscape, perceptions of beauty, favourite places, and sense of place. For generating locally specific narratives, we provided landscape maps of the commune in which interviewees could mark, 
for example, their favourite places or places that changed. We also used a ranking of photos with differing landscape features (natural spaces, monoculture, people in nature). Those methods were only used to stimulate the interviewees and keep their answers grounded in the local environment. Regarding landscape change, we asked for perceived changes in the last 20 years, how these influenced interviewees' lives, and how interviewees perceived the trajectory of changes for the coming 20 years. The translated interview guideline can be found in the supplementary material.

We interviewed a diversity of informed laypersons and experts who we expected to be connected to a given landscape (e.g. farmers, foresters, policy makers, longterm inhabitants, and clergy). These actors were identified through literature and online research on the given commune. We then used snowball sampling to reach possible interviewees and cover contrasting opinions (Flick 2006). Snowball sampling was especially necessary as contrasts in the communes led to mistrust against academic institutions, which we had to counter. This approach resulted in 34 interviews (Bispingen $=17$, Dötlingen $=17$ ). The interviews had an average length of $75 \mathrm{~min}$. and were conducted in German by the first author. Our study did not aim to be representative for the chosen communes but instead provide in-depth understanding of the influences of landscape simplification on relational values and human-nature connectedness.

\section{Data analysis}

Interviews were transcribed literally and analysed with MaxQDR Plus 12 (VERBI GmbH). Data were analysed using qualitative summarizing content analysis (Mayring 2008). The coding sought to capture both human-nature connectedness and those relational values that refer to the human collective and individual values related with and fostered by landscapes. To this end, we used the following procedure for data analysis. In a first step, based on material, experiential, cognitive, emotional and philosophical dimensions of human-nature connectedness research (Ives et al 2017, 2018) (Table A1), we created a deductive coding tree which was iteratively adjusted inductively, driven by the narratives and topics raised by the interviewees. The initial deductive approach helped to focus on topics such as the dimensions of human-nature connectedness and relational values, while the subsequent inductive cycles ensured that the priorities and meanings of the interviewees were captured in detail. For the inductive approach, new codes were successively grouped together to form categories of an increasing level of abstraction. The resulting categories of this qualitative content analysis can be found in Table 1. During this process, we aimed at preserving the qualitative character of interviewees' statements.
In a second step, we analysed the results of the human-nature connections in terms of other relational values, based on Chan et al. (2016). We considered as relational values those referring to (1) the human collective (cultural identity, social cohesion, social responsibility, social memory), and (2) primarily individual values (individual identity, stewardship eudaimonic and stewardship principle, ecological literacy, sense of agency and sense of place) (Tables 1 and 2).

Finally, we coded interviewees' statements regarding their perceived land-use changes and whether these changes were associated with human-nature connectedness (Table 3). To assess relationships between dimensions of human-nature connectedness, relational values and landscape simplification we extracted stated relationships: for example, we may have coded an interviewee's statement into the category of emotional connectedness, such as sense of place; which is also a relational value; and an interviewee may perceive this to be impacted by landscape simplification.

\section{Results}

The interviews revealed a wide variety of human-nature connections and relational values. In the first section, we explain how the five dimensions of human-nature connectedness were perceived and influenced by landscape simplification (Table 3). In the second section, we present findings regarding the interactions between human-nature connectedness and relational values. Finally, we highlight the effects of landscape simplification on the links between human-nature connectedness and relational values.

\section{Landscape simplification effects on human-nature connectedness}

Different types of connectedness were influenced by landscape simplification in various ways-some types changed without fundamentally declining, while others were perceived to be declining.

Material connectedness was generally perceived to have declined, driven by an increase in industrialised food production. Due to the structural transformation in the agricultural system, which included a decrease of smallholder farms and intensification of agricultural production, local food, feed and fuel were often exported from the region. The size and use of home gardens used for growing food were perceived to be decreasing, as were the use and availability of local products supplied by small shops belonging to smallholder farms. These changes in material human-nature connectedness were perceived to negatively affect interactions with the local environment. In addition to associations with farming, material connectedness was 
Table 1 Dimensions of humannature connectedness (HNC) (sensu Ives et al 2017) and their definition stemming from the inductive data analysis

\begin{tabular}{|c|c|}
\hline $\mathrm{HNC}$ & Definition of human-nature connections \\
\hline \multirow[t]{2}{*}{ Material } & Local products with symbolic values \\
\hline & Knowing where food comes from \\
\hline \multirow[t]{3}{*}{ Experiential } & Passive and active recreation \\
\hline & Social events in nature \\
\hline & Childhood spent in nature \\
\hline \multirow[t]{2}{*}{ Cognitive } & Knowledge on local culture and landscape \\
\hline & Knowledge on sustainability topics \\
\hline \multirow[t]{3}{*}{ Emotional } & Negative and positive emotions to nature \\
\hline & Emotions regarding the trajectory of land-use changes \\
\hline & Sense of place and regional identity \\
\hline Philosophical & Treating nature appropriately \\
\hline Relational values & Definition of relational values \\
\hline Cultural identity & Identity of local culture linked with a landscape \\
\hline Individual identity & Personal identity linked with a landscape \\
\hline Social responsibility & $\begin{array}{l}\text { Care for a landscape is seen as similar as caring for its people in the } \\
\text { present and future }\end{array}$ \\
\hline Social cohesion & Sense of belonging and equality in the commune regarding a landscape \\
\hline Social memory & History of the commune and its people linked with a landscape \\
\hline Social relations & People connect with each other while being in the landscape \\
\hline Sense of place & Attachment to landscape or certain places \\
\hline Sense of agency & Awareness to execute or control aspects of landscapes \\
\hline Spirituality & Mystical or religious feelings stemming from a certain landscape or place \\
\hline Stewardship principle & Taking care of the landscape is the right thing to do \\
\hline Stewardship eudaimonic & Care for landscapes is necessary for a good life \\
\hline Ecological literacy & Knowledge on ecological aspects and connections in landscapes \\
\hline
\end{tabular}

Relational values (sensu Chan et al 2016) and their definitions as stemming from the inductive data analysis

Table 2 General links between five dimensions of human-nature connectedness (HNC) and relational values based on the qualitative content analysis

\begin{tabular}{lll}
\hline HNC & Definition of HNC & Linked relational values \\
\hline Material & Local products with symbolic values & Cultural identity \\
& Knowing where food comes from & Stewardship eudaimonic; Social responsibility \\
Experiential & Passive and active recreation & Stewardship eudaimonic \\
& Social events in nature & Social cohesion; Social relations; Cultural identity \\
& Childhood spent in nature & Individual identity; Social memory \\
Cognitive & Knowledge on local culture and landscape & Cultural identity; Ecological literacy \\
& Knowledge on sustainability topics & Stewardship principle; Ecological literacy \\
Emotional & Negative and positive emotions to nature & Individual identity; Social responsibility \\
& Emotions regarding the trajectory of land-use changes & Stewardship principle; Sense of place; spiritual values; sense of agency; \\
& & Social cohesion \\
& Sense of place/regional identity & Cultural identity; Sense of place \\
Philosophical & Treating nature appropriately & Stewardship principle; Stewardship eudaimonic; Social responsibility; \\
& & Sense of agency; Social cohesion \\
\hline
\end{tabular}

occasionally associated with local natural materials used for heating, building, decoration or collection of wild fruit or herbs.
In contrast to material connectedness, experiential connectedness was perceived to be stronger, and comparably less influenced by landscape simplification. Generally, interviewees spent a large amount of time in nature in 
Table 3 Examples of the effects of landscape simplification and related drivers on human-nature connectedness and relational values in the two study areas

\begin{tabular}{|c|c|c|c|}
\hline $\mathrm{HNC}$ & Main stated drivers of HNC loss & Main impacted relational values & Exemplary quotes \\
\hline Material & $\begin{array}{l}\text { Agricultural intensification; Global pro- } \\
\text { duction of food; Subsidies for renew- } \\
\text { able energies }\end{array}$ & Cultural identity; Ecological literacy & $\begin{array}{l}\text { Because they don't know anymore } \\
\text { what meat actually means and what it } \\
\text { is. And everyone is turned off when } \\
\text { you see a slaughterhouse on TV. But } \\
\text { the [agricultural] structure and how } \\
\text { it reached the slaughterhouse [is not } \\
\text { shown...]. That there has been a devel- } \\
\text { opment [of disconnection; ...] and this } \\
\text { is not discussed (Bispingen, farmer } \\
\text { about the disconnect from material } \\
\text { HNC through spatial distance and lack } \\
\text { of visibility) }\end{array}$ \\
\hline Experiential & $\begin{array}{l}\text { Agricultural intensification; Parents } \\
\text { disconnected from nature; } \\
\text { Multiple competing activities; }\end{array}$ & $\begin{array}{l}\text { Stewardship eudaimonic Cultural identity } \\
\text { Social cohesion; Social memory }\end{array}$ & $\begin{array}{l}\text { This [nature experiences] also vanished } \\
\text { through the parents. We don't have } \\
\text { farms anymore; one doesn't really take } \\
\text { the kids and go places to see what's } \\
\text { creeping and crawling there (Bispin- } \\
\text { gen, teacher on the disconnect from } \\
\text { experiential HNC through lack of } \\
\text { planned experiences) }\end{array}$ \\
\hline Cognitive & Landscape simplification & $\begin{array}{l}\text { Stewardship eudaimonic; Cultural iden- } \\
\text { tity; Ecological literacy }\end{array}$ & $\begin{array}{l}\text { In the last } 10 \text { years, I would say, it [the } \\
\text { blame towards farmers] increased. } \\
\text { Farmers are polluters, farmers torment } \\
\text { animals, farmers contaminate the } \\
\text { groundwater, farmers are generally } \\
\text { responsible for all bad things found } \\
\text { in nature (Dötlingen, farmer about } \\
\text { the biased knowledge on landscape } \\
\text { simplifications) }\end{array}$ \\
\hline Emotional & $\begin{array}{l}\text { Agricultural intensification; } \\
\text { Landscape simplification }\end{array}$ & $\begin{array}{l}\text { Stewardship eudaimonic; Cultural } \\
\text { identity; } \\
\text { Social cohesion; Cultural identity }\end{array}$ & $\begin{array}{l}\text { There are developments here in the land- } \\
\text { scape [landscape simplification], which } \\
\text { I just don't consider aesthetic. Where } \\
\text { I simply say that those disturbances } \\
\text { bother me, and they hurt me (Bisp- } \\
\text { ingen, forester about the emotional } \\
\text { impact of the amount of maize, and } \\
\text { impacts of nutrients in the forests) }\end{array}$ \\
\hline Philosophical & Agricultural intensification & $\begin{array}{l}\text { Stewardship eudaimonic; Sense of } \\
\text { agency; } \\
\text { Stewardship principle/virtue }\end{array}$ & $\begin{array}{l}\text { They really employ an [external] } \\
\text { agricultural service to work the fields. } \\
\text { Then there are young people sitting } \\
\text { on the tractor, with no connection to } \\
\text { the specific soil and they smash up } \\
\text { everything that is not nailed down } \\
\text { (Dötlingen, Environmentalist about } \\
\text { the industrialisation of agriculture for } \\
\text { economic gain) }\end{array}$ \\
\hline
\end{tabular}

Exemplary quotes are presented for the five dimensions of human-nature connectedness (HNC)

consequence of their profession, voluntary engagement or leisure activities. Due to the time constraints of daily life, many experiences in nature were unplanned or bound to the area close to people's work and living spaces. Hence, when interviewees' direct surroundings experienced rapid land simplification and agricultural intensification, experiential connectedness towards those spaces declined, and we observed a retreat of people into their own gardens or other spaces for nature experiences. While there was a trend that indicated hiking had increased, especially in the Lueneburg Heath, day-to-day nature experiences for most inhabitants were perceived as decreasing. Interviewees raised the issue of alienation from nature, stating that disconnected parents were unable or unwilling to experientially connect their children with nature. Further, the decrease of smallholder farms was perceived to negatively influence experiential 
connectedness because of the lack of possible passive and active interactions with local farmers and their farms.

Cognitive connectedness, as knowledge and awareness of the natural environment, was related to the motivation to see and experience something new. Interviewees perceived it to be connected to stimulating experiences including animal sightings, special activities or memorable adventures. The new, unknown or attractive sights of historical, natural or aesthetically valuable places were a motivation to go out into nature. Environmental education was generally seen as very important, and both areas offered many possibilities for this. Using all five senses was highlighted as important for children's education and to sensitise children for nature. Overall, our findings suggest that cognitive connectedness was relatively high, despite ongoing landscape simplification. However, it was also discussed how knowledge and awareness about problems in the regions seemed not to lead to any significant behavioural change, and hence might not be enough to create meaningful change for sustainability.

Similarly to cognitive connectedness being fostered by stimulating experiences in diverse or structurally rich parts of the landscape, emotional connectedness also appeared to be related to biodiversity and landscape multifunctionality. Landscape simplification was generally perceived to have a negative effect on landscape aesthetics because monofunctional landscapes were seen as less beautiful. Through increasing monocultures, intensification and a general increase of infrastructure, inhabitants feared that the landscape's horizon may lose its sense of naturalness. We also found notions of anger and despair when it came to the topic of landscape simplification or the statement of general detachment from nature in society. One interviewee expressed the experience of watching the landscape simplification and growing disconnection between humans and nature with strong emotions: "[...] a great, deep, fundamental pain, grief. Despair. Helplessness. Or often again a bewilderment about this state of semi-sleep [due to lack of agency]" (Dötlingen, inhabitant). General love for nature was expressed with regard to old trees, special natural or historical sites, or animal sightings. Spiritual notions were linked to special or mystic atmospheres of places, such as early mornings in a foggy, calm heathland.

Finally, with respect to philosophical connections to nature, interviewees used a range of constructs, acknowledging the tensions between instrumental values of nature, such as the importance of nature for people's livelihoods, and values, such as the duty of care towards the environment. Interviewees frequently stated instrumental values when considering that nature's purpose was that it had to sustain livelihoods and could be used for recreational purposes. While environmental protection was seen as necessary, managing the land for humans was widely held as equally important. Many interviewees showed a feeling of unease and insecurity when it came to the current development of the landscape. Without being specifically prompted, interviewees often focussed on contrasts and tensions within the region as well as problematic narratives of (economic) growth when talking about landscape simplification. This discussion unravelled differing understandings of agriculture and environmental protection and often pointed to hardened ideological fronts- "The facts are just created [felling of trees and ploughing up marshlands], and then it is destroyed. And you are standing there and you are thinking: yeah. And now it is broken, what should I do now?" (Dötlingen, employee in local administration).

\section{Interlinkages between human-nature connectedness and relational values}

When interviewees discussed human-nature connections, they often also referred to relational values-focussing on their decrease as a result of landscape simplification. In terms of material connectedness, interviewees stated that the general notion of knowing where the food comes from is very important, and this was linked to values of a good life (stewardship eudaimonic, social responsibility). Similarly, some material goods had a symbolic character for cultural identity, such as regional specialty foods like certain types of potatoes or honey (Table 2).

Regarding experiential connections, especially passive recreation, respondents stated that they were very important for relaxation, solitude and quietness, and hence were linked to values of a good life (i.e. stewardship eudaimonic). Further, nature was valued as a backdrop for social events or as the focus for social gatherings, thus contributing to the quality of social cohesion and social relations. Such experiential connections also contributed to cultural identity in relation to their landscape, as one interviewee explained: "[in former times] the whole village community always met and went to "entkusseln" [a type of landscape conservation which removes shrubs and young trees] in the heath land. So that the heath stays beautiful" (Bispingen, inhabitant). Activities such as these strengthened the feeling of a shared cultural identity connected to "their" heathlands. Interviewees also drew on stories of their own childhood experiences in nature, which they believed led to a stronger connection to nature (i.e. individual identity, social memory).

Respondents often raised the relational value of cultural identity in regards to cognitive connectedness. Interviewees were concerned about the effect of landscape simplification on people's knowledge of nature, including formal knowledge through work and informal knowledge through inheritance and self-taught. Topics raised included knowledge of the landscape such as its cultural, historical and natural specifications. Further the interviewees' knowledge on environmental protection and sustainability was linked to 
statements of how nature should be treated (i.e. stewardship principle), as stated by one interviewee: "Only then [referring back to the co-creation of knowledge and awareness of nature], when there is a connection, then I feel responsible for something; or I consider something beautiful, or there is an effect of recognition with people that I meet. Only then, can I engage [in nature]" (Dötlingen, environmentalist).

Emotional connectedness ranged from positive to negative emotions and respondents linked these with certain relational values. On the positive spectrum, both study areas had a very strong sense of cultural identity. Especially in Bispingen, the Lueneburg Heath was seen as a special area and its inhabitants often felt a sense of place or spiritual connections to certain places. Negative emotions towards landscape simplification were related to impacts on individual identity, diminished social cohesion and deteriorating social relations. In addition, the negative emotion of frustration emerged when interviewees considered simplification as an inappropriate trajectory of the landscape, expressing the relational values of stewardship principle and social responsibility. "I am very very critical of this development [intensification/simplification]. And some things scare me. I am usually a positive person...or a positive thinking person... but some things really scare me" (Dötlingen, forester).

In statements on philosophical connections, interviewees expressed opinions that nature was seen as fragile and it was deemed necessary to treat it well or give something back (stewardship principle) including the sense of agency to do so. Nature was also stated to be as essential for a good life (stewardship eudaimonic). This was, for example, stated by farmers with a high attachment to their own land and the future development of it, or related to the hunters' paradigms of "protection and care" (German: Hege und Pflege): "We are a family business which grew decades, centuries. And we cannot leave this place, and hence we have to care for it, not emaciate and then move on. [...] especially for older farms and heath farms, this [stewardship] is obvious" (Bispingen, farmer).

\section{Effect of landscape simplification on the interlinkages between human-nature connectedness and other relational values}

While patterns in human-nature connectedness were broadly similar in both study areas, interviewees stated more negative influences of landscape simplification on relational values in Dötlingen (Table 3). By contrast, in Bispingen we observed fewer statements regarding the effect of landscape simplification on relational values and human-nature connectedness.

In Bispingen, the protected area status of the area constrained the growth of agriculture, leading to "smaller" farms with more livelihood diversity that included other experiences in nature, such as tourism and recreation. In fact, tourism in the Lueneburg Heath had long been a strong factor in the region for economic activities and for forming a cultural identity: "this is what defines our commune, that we have this landscape, this heath" (Bispingen, farmer). The diversity of experiences, in turn, was related to collaboration among local actors: "Of course everyone has to look out for himself, but among farmers there is a real sense of unity, there are no animosities here" (Bispingen, farmer). While conflicts and tensions existed, dialogue was seen as the best option to reach transparent decisions.

In contrast, the landscape in Dötlingen had seen uneven growth favouring a few, increasingly larger farms that focus in intensive agriculture. The growth of those farms had now reached limiting factors such as land availability and increased rents, as well as national emissions regulations that limit the construction of new mass husbandry stables. The growth of farm sizes seemed to be associated with a decline in people identifying with the surrounding landscapes. It also seemed to give rise to the alienation between fractions, such as smaller and bigger farmers and environmental protection groups: "When you are constantly told that you are the bogeyman of the nation, you are not willing to voluntarily give in to anyone. You'd rather say: as long as you treat me like this, I won't do anything here" (Dötlingen, farmer). One employee in the local administration in Dötlingen who works in environmental conservation expressed a similar sentiment, albeit directed against intensification: "I just don't want this anymore. And I think: then just do your shit, just let it go your way. I don't want to say something against it all the time. You will see what the outcome is. [...] and I am not the only one having this effect [i.e. no feeling this way]". To continue working in agriculture, farms were increasingly pushed to focus on efficient production, which fostered instrumental values. This stood, in contrast, with the sense of place and cultural heritage inhabitants valued but felt disappearing through agricultural intensification of the landscape. In Dötlingen, a feeling of lack of agency and frustration with the current trajectory of land simplification emerged among interviewees. This led to people retreating into their own homes (where they had agency) or expressing anger (Table 3): "I really think if we continue like this, with industrial animal husbandry and intensive agriculture, then our soil will be so damaged that nothing will grow, because that's it!" (Dötlingen, tourism operator). 


\section{Discussion}

\section{Effects of landscape simplification on human- nature connectedness and relational values}

Landscape simplification is occurring all over the world and increasingly shaped by global drivers rather than local ones (Foley et al 2005). Ecological effects of landscape simplifications are well known and studied, such as negative influence on wild biodiversity (Green et al 2005), farmland biodiversity (Tscharntke et al 2005), and the diversity of crop varieties (FAO 2011). Here, we highlight the impacts of landscape simplification on non-material NCP through the analysis of human-nature connectedness and relational values, particularly when the changes are rapid (Fig. 2). Our qualitative and explorative empirical work does not aim to give a representative overview of the two communes but rather highlight the various negative influences of landscape simplification of a small group of knowledgeable persons. Further research on quantifying $\mathrm{HNC}$ and other relational
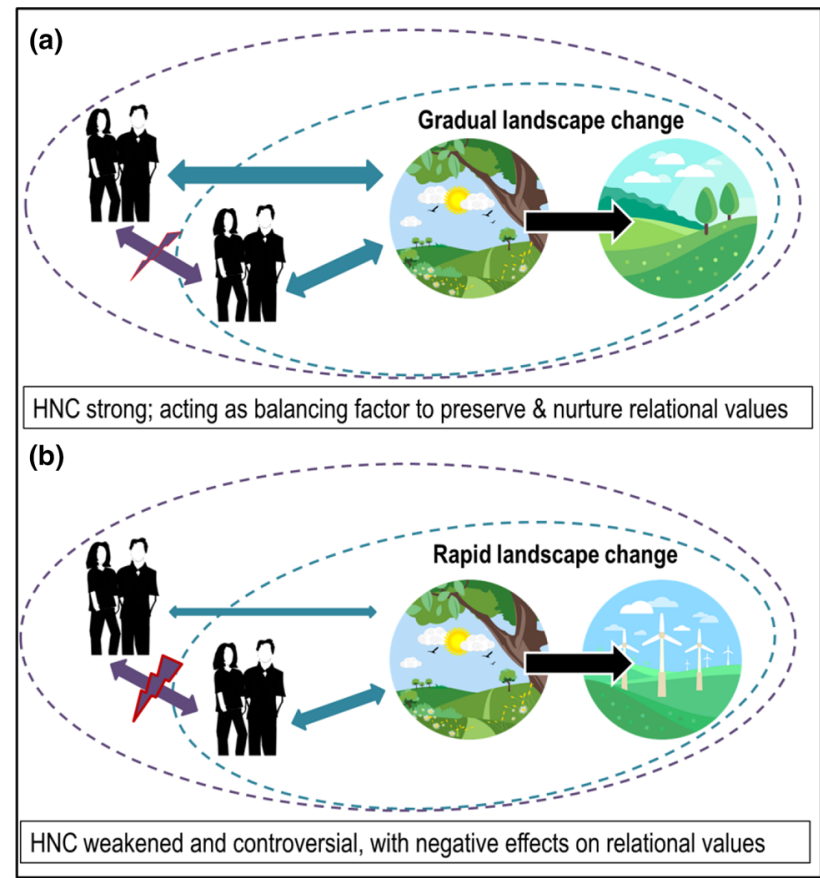

Fig. 2 Outer circle: relational values involving the human collective. Inner circle: primarily individual relational values. Blue arrows represent relations between humans and landscape $=$ human-nature connectedness in different strengths and conceptualizations. Purple arrows show relations between people $=$ social relationships. The width of the arrows denotes the hypothesized strength of a given connection; potential breakdown or conflict is indicated by a lightning symbol. Landscape pictograms show landscape change from gradual and minor (a) to rapid and major (b). HNC Human-nature connectedness. Source: Landscape icons made by Freepik \& Icon Pond from www.flaticon.com values and relating these to concrete landscape changes might be an interesting future endeavor.

Our results, especially in Dötlingen, indicate a landscape under stress. With the influence of landscape simplification on inhabitants' sense of place and moral compass regarding "what kind of development is right for this area", contrasting ideological fronts have begun to diminish social coherence and social relations. Notably, the situation in Bispingen was less conflict-laden. Here, land-use change was limited due to the protected area status, and income diversification had been practiced for decades. Tourism activities in the area had strengthened regional identity and pride in those diverse landscapes. Collaboration among local government, farmers and tourism operators was high. Still the necessity to grow and intensify to allow an economically stable future, together with the restrictions imposed by the natural park, constantly challenged local farmers. This fostered disagreements and even caused a court case led by some farmers to reclaim land currently leased to the natural park. However, despite such challenges, the general understanding in Bispingen was not one of direct, personal blame but a sentiment of lack of ascribed responsibility and loss of agency. There was a feeling of an, often unidentified, outside force that was changing the system and making people behave in unsustainable ways.

\section{Human-nature connectedness as balancing factor for preserving and nurturing relational values under Landscape simplification}

Based on our findings, we argue that the multi-facetted dynamics in human-nature connectedness played a balancing role on the effect landscape simplification had on relational values. Relational values such as cultural or individual identity and social relations appeared to be partly mediated by human-nature connectedness (Fig. 2a). A strong emotional connection to the landscape expressed and shared by inhabitants may increase social coherence within the communities and strengthen social relationships. A similar effect may be hypothesized for a strong experiential connection, as many experiences in the landscapes are shared with family members, friends or other inhabitants (Balázsi et al 2019). However, groups may have different preferences and compositions of human-nature connectedness, i.e. a different understanding of what nature is, and what it should and could be used for. In gradually simplified landscapes, these differing understandings and connections can co-exist. However, when change becomes more rapid and natural spaces rarer, the contrasting preferences might lead to conflicts (Riechers et al 2018).

Rapid landscape simplification can decrease and change human-nature connectedness and, in turn, lead to starkly contrasting value preferences between actor groups (such 
as prioritisation on instrumental values vs. sense of place or spiritual values) (Fig. 2b) (Riechers et al 2019a). The decrease of human-nature connectedness and the differing constitutions of those dimensions can lead to an erosion of certain relational values, such as cultural identity and social relations (Table 3). Hence, we postulate that landscape simplification is likely to have negative consequences for a broad range of relational values in many instances (Table 3), possibly even leading to a vicious cycle of disconnection and disengagement in the community. We also suggest that when landscape simplification affects relational values, it may lead to conflicts between individuals and actor groups (Fig. 2b) (Riechers et al 2019a). Our results contribute to current discussions on how relational values can build a better understanding of possible conflicts between social actors (Chapman et al 2019; Topp et al 2020). For example, Chapman et al. (2019) found that conflicts between farming and conservation programs could be meliorated by considering the relational values of farmers in terms of their identity.

A relational values lens highlights the links between humans and nature through tangible and intangible relationships. In our results, this is especially present in the emotional and philosophical human-nature connections as our respondents clearly highlighted the repercussions those have on (1) the relationships between community members and groups, and (2) the moral and ethical considerations of the inhabitants. The overarching normative questions of "where do we want to go" and "who owns a landscape" were addressed, as many interviewees wished for a system that allows a stable income in agriculture without focusing narrowly on profit maximisation with high economic risks, while also ensuring sustainable land use.

\section{Activating the leverage point of human-nature connectedness}

By highlighting the strong links between human-nature connectedness, relational values and landscape simplification, we emphasise the crucial role of connectedness to nature as a leverage point for sustainability (Abson et al. 2017; Fischer and Riechers 2019). Leverage points are places in a complex system in which small interventions can have wide-ranging influences to bring about system change (Meadows 1999), and intervening at key leverage points holds great potential for system transformation (Abson et al. 2017). Here, we defined leverage points as domains for interventions that can result in observable changes within a system (Manlosa et al. 2018). While most efforts to combat detrimental environmental changes have focused on changing specific parameters (e.g. the rate of land clearing) or relationships between parameters (e.g. increasing fines to prevent illegal land clearing), this often has not fundamentally changed the trajectories of the systems (Fischer et al. 2007). Addressing more deeply root causes of unsustainability in contrast, is more difficult to do but may hold greater potential for longterm system transformation (Fischer et al. 2012; Abson et al. 2017). Strengthening human-nature connectedness could be one potential leverage point to foster sustainability transformation (Riechers et al. 2020a) but is also deeply affected by landscape simplification (Riechers et al. 2020b).

Based on our analysis, we identified two domains for interventions seeking to enhance human-nature connectedness to improve sustainability. First, fostering collective knowledge generation to enable information flow and exchange can create mutual empathy and understanding, and thus combat slipping into unconstructive scapegoating (Riechers et al. 2019a). In Bispingen, collaborations between smaller and bigger farmers were strong, and while problems existed, communication and collaboration with environmental conservation groups and other inhabitants also flourished. Our research showed that there was an understanding that farmers are forced to grow and to intensify their agriculture due to national policies, however, anger and blame from both sides still emerged—often stating a lack of understanding of agro-political processes (see also Allen et al. 2018; Chapman et al. 2019). Our results support previous research that found that meaningful participatory processes would be favourable to stop a spiral of disengagement and apathy by strengthening information flow, creating knowledge and a sense of agency.

Second, the motivation and engagement arising from emotional discomfort could be harnessed to actively foster local transformational change as seen fit by the actors involved (Riechers et al. 2019a). Due to the intertwined and interlinked nature of human-nature connectedness and relational values such as social relations and eudaimonic values, we reason that interventions in these domains could nurture and foster a broad range of relational values (Capaldi et al. 2014; Riechers et al. 2019b). Especially interventions to strengthen emotional and experiential human-nature connectedness are pivotal, due to their multiple links to other dimensions of connectedness (Riechers et al. 2020a). This would lead to strengthening the overall human-nature connectedness and ultimately, may improve sustainability outcomes.

There is a clear need for transformative change that permeates entire social systems-from the emotions of individuals to attitudes of social groups, and ultimately to societal structures and processes. If state policies and interventions are to be effective in addressing landscape simplification and the far-reaching consequences, these will need to go beyond a focus on specific environmental parameters, and instead engage with deeper leverage points such as values and emotions (Riechers et al. 2020b). This will include confronting issues of changing and inequitable agency of residents, farmers and government 
bodies. Many actors in a given landscape may wish for a transformational shift in the landscape trajectory, but a feeling of helplessness and inability to change existing economic and political systems often not adjusted to the landscape can substantially undermine their ability to actually work towards transformation (Chapman et al. 2019).

\section{Conclusion}

This study shows that landscape simplification can have farreaching consequences on human-nature connectedness and relational values, fostering discomfort and concern in rural residents regarding future development pathways. Our study uncovers a nuanced perception of human-nature connectedness broadly distinguished into material, experiential, cognitive, emotional and philosophical dimensions. Further, we highlight the benefits of a relational values lens that combines human-nature connectedness with other relational values including those concerned with the human collective or primarily individual values. Human-nature connectedness and other relational values seem to be tightly interlinked and negatively impacted by increasingly rapid landscape simplification. We postulate that improved human-nature connectedness could buffer the negative impacts of landscape simplification on relational values, such as social relations and cultural identity. Based on our findings, we propose three domains of intervention that could act as leverage points to foster sustainability: (1) strengthening transparency and information flow and exchange, (2) tapping into the discomfort arising from landscape simplification as a source for motivating transformation, and (3) using meaningful participatory processes to stop a vicious cycle of disconnection and disengagement with a landscape and its people. The influence of landscape simplification on the relationship between human-nature connectedness and relational values deserves further research in different study areas to gain a deeper understanding on how the leverage point of human-nature connectedness may help to preserve and nurture relational values.

Supplementary Information The online version contains supplementary material available at https://doi.org/10.1007/s11625-021-00928-9.

Acknowledgements We thank the interviewees for their collaboration. This research is supported by the Volkswagenstiftung and the Niedersächsisches Ministerium für Wissenschaft und Kultur (Grant Number A112269). This research draws on work undertaken in a large transdisciplinary research project (Leverage Points for Sustainability Transformation). The author(s) acknowledge and thank all project members for their ideas and input in the early stages of this work, even where they are not listed as authors. Full details of project members and their research are available at https://leveragepoints.org.
Funding Open Access funding enabled and organized by Projekt DEAL.

Open Access This article is licensed under a Creative Commons Attribution 4.0 International License, which permits use, sharing, adaptation, distribution and reproduction in any medium or format, as long as you give appropriate credit to the original author(s) and the source, provide a link to the Creative Commons licence, and indicate if changes were made. The images or other third party material in this article are included in the article's Creative Commons licence, unless indicated otherwise in a credit line to the material. If material is not included in the article's Creative Commons licence and your intended use is not permitted by statutory regulation or exceeds the permitted use, you will need to obtain permission directly from the copyright holder. To view a copy of this licence, visit http://creativecommons.org/licenses/by/4.0/.

\section{References}

Abson DJ, Fraser ED, Benton TG (2013) Landscape diversity and the resilience of agricultural returns: a portfolio analysis of land-use patterns and economic returns from lowland agriculture. Agric Food Secur 2:2. https://doi.org/10.1186/2048-7010-2-2

Abson DJ, Fischer J, Leventon J et al (2017) Leverage points for sustainability transformation. Ambio 46:30-39. https://doi.org/ 10.1007/s13280-016-0800-y

Allen KE, Quinn CE, English C, Quinn JE (2018) Relational values in agroecosystem governance. Curr Opin Environ Sustain 35:108-115. https://doi.org/10.1016/j.cosust.2018.10.026

Arias-Arévalo P, Martín-López B, Gómez-Baggethun E (2017) Exploring intrinsic, instrumental, and relational values for sustainable management of social-ecological systems. E\&S. https:// doi.org/10.5751/ES-09812-220443

Balázsi Á, Riechers M, Hartel T et al (2019) The impacts of socialecological system change on human-nature connectedness: a case study from Transylvania. Romania Land Use Policy 89:104232. https://doi.org/10.1016/j.landusepol.2019.104232

Capaldi CA, Dopko RL, Zelenski JM (2014) The relationship between nature connectedness and happiness: a meta-analysis. Front Psychol 5:976. https://doi.org/10.3389/fpsyg.2014.00976

Chan KMA, Balvanera P, Benessaiah K et al (2016) Opinion: why protect nature? Rethinking values and the environment. Proc Natl Acad Sci USA 113:1462-1465. https://doi.org/10.1073/ pnas. 1525002113

Chan KM, Gould RK, Pascual U (2018) Editorial overview: relational values: what are they, and what's the fuss about? Curr Opin Environ Sustain 35:A1-A7. https://doi.org/10.1016/j. cosust.2018.11.003

Chapman M, Satterfield T, Chan KMA (2019) When value conflicts are barriers: can relational values help explain farmer participation in conservation incentive programs? Land Use Policy 82:464-475. https://doi.org/10.1016/j.landusepol.2018.11.017

Di Falco S, Perrings C (2003) Crop genetic diversity, productivity and stability of agroecosystems. A theoretical and empirical investigation. Scott J Polit Econ 50:207-216. https://doi.org/ 10.1111/1467-9485.5002006

Díaz S, Pascual U, Stenseke M et al (2018) Assessing nature's contributions to people. Science 359:270-272. https://doi.org/10. $1126 /$ science.aap 8826

Díaz S, Settele J, Brondízio ES et al (2019) Pervasive human-driven decline of life on Earth points to the need for transformative change. Science. https://doi.org/10.1126/science.aax3100 
FAO (2011) Report of the panel of eminent experts on ethics in food and agriculture. FAO (Food and Agriculture Organization of the United Nations), Rome

Fischer J, Riechers M (2019) A leverage points perspective on sustainability. People Nat. https://doi.org/10.1002/pan3.13

Fischer J, Manning AD, Steffen W et al (2007) Mind the sustainability gap. Trends Ecol Evol (Amst) 22:621-624. https://doi. org/10.1016/j.tree.2007.08.016

Fischer J, Dyball R, Fazey I et al (2012) Human behavior and sustainability. Front Ecol Environ 10:153-160. https://doi.org/10. $1890 / 110079$

Fischer J, Abson DJ, Butsic V et al (2014) Land sparing versus land sharing: moving forward. Conserv Lett 7:149-157. https://doi. org/10.1111/conl.12084

Fischer J, Meacham M, Queiroz C (2017) A plea for multifunctional landscapes. Front Ecol Environ 15:59-59. https://doi.org/10. $1002 /$ fee. 1464

Flick U (2006) Qualitative Sozialforschung, 4th edn. Rowohlt Taschenbuch Verlag GmbH, Reinbek bei Hamburg

Foley JA, Defries R, Asner GP et al (2005) Global consequences of land use. Science 309:570-574. https://doi.org/10.1126/science. 1111772

Folke C, Jansson A, Rockström J et al (2011) Reconnecting to the biosphere. Ambio 40:719-738. https://doi.org/10.1007/ s13280-011-0184-y

Grass I, Loos J, Baensch S et al (2019) Land-sharing/-sparing connectivity landscapes for ecosystem services and biodiversity conservation. People Nat. https://doi.org/10.1002/pan3.21

Green RE, Cornell SJ, Scharlemann JPW, Balmford A (2005) Farming and the fate of wild nature. Science 307:550-555. https://doi.org/ 10.1126/science. 1106049

Himes A, Muraca B (2018) Relational values: the key to pluralistic valuation of ecosystem services. Curr Opin Environ Sustain 35:1-7. https://doi.org/10.1016/j.cosust.2018.09.005

Intergovernmental Science-Policy Platform on Biodiversity and Ecosystem Services I (2019) Summary for policymakers of the global assessment report on biodiversity and ecosystem services. Zenodo. https://doi.org/10.5281/zenodo.3553579

Ives CD, Giusti M, Fischer J et al (2017) Human-nature connection: a multidisciplinary review. Curr Opin Environ Sustain 26-27:106113. https://doi.org/10.1016/j.cosust.2017.05.005

Ives CD, Abson DJ, von Wehrden $\mathrm{H}$ et al (2018) Reconnecting with nature for sustainability. Sustain Sci 13:1389-1397. https://doi. org/10.1007/s11625-018-0542-9

Klain SC, Olmsted P, Chan KMA, Satterfield T (2017) Relational values resonate broadly and differently than intrinsic or instrumental values, or the New Ecological Paradigm. PLoS ONE 12:e0183962. https://doi.org/10.1371/journal.pone.0183962

Landesamt für Statistik Niedersachsen (2018a) Katasterfläche nach Nutzungsarten (17) der tatsächlichen Nutzung (Gemeinde; Zeitreihe). Gebietsstand: 1.1.2015. Landwirtschaftliche Fläche (ohne Moor \& Heide) von 1997, 2015. . http://www1.nls.niede rsachsen.de/statistik/html/default.asp. Accessed 3 May 2018

Landesamt für Statistik Niedersachsen (2018b) Agrarstrukturerhebung, Landwirtschaftszählung. Private Data. Accessed 3 May 2018

LSN (2019a) Landesamt für Statistik, Meine Gemeinde, meine Stadt - ausgewählte Daten auf Verwaltungseinheitsebene (VE) - Gebietsstand: 01.11.2016. http://www. nls.niedersachsen.de/gemeinden/G358002.html. Accessed 14 Feb 2019

LSN (2019b) Katasterfläche nach Nutzungsarten (16) der tatsächlichen Nutzung" (Gemeinde; Zeitreihe), Katasterfläche in Niedersachsen (Gebietsstand: 1.07.2017). https://www1.nls.niedersachsen. de/statistik/html/default.asp. Accessed 14 Feb 2019

Maller C, Townsend M, Pryor A et al (2006) Healthy nature healthy people: "contact with nature" as an upstream health promotion intervention for populations. Health Promot Int 21:45-54. https:// doi.org/10.1093/heapro/dai032

Manlosa AO, Schultner J, Dorresteijn I, Fischer J (2018) Leverage points for improving gender equality and human well-being in a smallholder farming context. Sustain Sci 14:1-13. https://doi.org/ 10.1007/s11625-018-0636-4

Mayer FS, Frantz CM (2004) The connectedness to nature scale: a measure of individuals' feeling in community with nature. J Environ Psychol 24:503-515. https://doi.org/10.1016/j.jenvp.2004.10. 001

Mayring P (2008) Qualitative inhaltsanalyse. Grundlagen und Techniken, 10th edn. Beltz Verlag, Weinheim/Basel

Meadows DH (1999) Leverage points: places to intervene in a system. The Sustainability Institute, Hartland

Meadows DH, Meadows DL, Randers J, Behrens WW (1972) The limits to growth. Universe Books, New York

Mikulcak F, Newig J, Milcu AI et al (2013) Integrating rural development and biodiversity conservation in Central Romania. Environ Conserv 40:129-137. https://doi.org/10.1017/S03768929120003 92

Nisbet EK, Zelenski JM, Murphy SA (2009) The nature relatedness scale: linking individuals' connection with nature to environmental concern and behavior. Environ Behav 41:715-740. https://doi. org/10.1177/0013916508318748

Landkreis Oldenburg (2018) Planen und Bauen/Bauen im LandkreisOldenburg/Biogasanlagen. . http://www.oldenburg-kreis.de/portal/ seiten/biogasanlagen-900000059-21700.html. Accessed 8 Mar 2018

Pascual U, Balvanera P, Díaz S et al (2017) Valuing nature's contributions to people: the IPBES approach. Curr Opin Environ Sustain 26-27:7-16. https://doi.org/10.1016/j.cosust.2016.12.006

Riechers M, Barkmann J, Tscharntke T (2018) Diverging perceptions by social groups on cultural ecosystem services provided by urban green. Landsc Urban Plan 175:161-168. https://doi.org/10.1016/j. landurbplan.2018.03.017

Riechers M, Henkel W, Engbers M, Fischer J (2019a) Stories of favourite places in public spaces: emotional responses to landscape change. Sustainability 11:3851. https://doi.org/10.3390/ su11143851

Riechers M, Strack M, Barkmann J, Tscharntke T (2019b) Cultural ecosystem services provided by urban green change along an Urban-Periurban gradient. Sustainability 11:645. https://doi.org/ $10.3390 /$ su11030645

Riechers M, Balázsi Á, Betz L et al (2020b) The erosion of relational values resulting from landscape simplification. Landsc Ecol. https://doi.org/10.1007/s10980-020-01012-w

Riechers M, Balázsi Á, Abson DJ, Fischer J (2020a) The influence of landscape change on multiple dimensions of human-nature connectedness. E\&S. https://doi.org/10.5751/ES-11651-250303

Shanahan DF, Bush R, Gaston KJ et al (2016) Health benefits from nature experiences depend on dose. Sci Rep 6:28551. https://doi. org/10.1038/srep28551

Soga M, Gaston KJ (2016) Extinction of experience: the loss of human-nature interactions. Front Ecol Environ 14:94-101. https:// doi.org/10.1002/fee. 1225

Stenseke M (2018) Connecting "relational values" and relational landscape approaches. Curr Opin Environ Sustain 35:82-88. https:// doi.org/10.1016/j.cosust.2018.10.025

Taniguchi ST, Freeman PA, Richards AL (2005) Attributes of meaningful learning experiences in an outdoor education program. J Adv Educ Outdoor Learn 5:131-144. https://doi.org/10.1080/14729 670585200661

Topp EN, Loos J, Martín-López B (2020) Decision-making fornature's contributions to people in the Cape Floristic Region: the role ofvalues, rules and knowledge. Sus Sci 
Tscharntke T, Klein AM, Kruess A et al (2005) Landscape perspectives on agricultural intensification and biodiversity-ecosystem service management. Ecol Lett 8:857-874. https://doi.org/10. 1111/j.1461-0248.2005.00782.x

Zylstra MJ, Knight AT, Esler KJ, Le Grange LLL (2014) Connectedness as a core conservation concern: an interdisciplinary review of theory and a call for practice. Springer Sci Rev 2:119-143. https:// doi.org/10.1007/s40362-014-0021-3
Publisher's Note Springer Nature remains neutral with regard to jurisdictional claims in published maps and institutional affiliations. 